\title{
Myostatin Gene Polymorphism in Local Horse Breeds
}

\author{
Lyudmila A. KHRABROVA $^{1^{*}}$, Sergey I. SOROKIN ${ }^{2}$, Nina V. BLOKHINA ${ }^{1}$, \\ and Tatyana V. KALASHNIKOVA ${ }^{1}$ \\ ${ }^{1}$ All-Russian Scientific Research Institute of Horse Breeding, 91105, Divovo, \\ Ryazan Region, Russian Federation \\ ${ }^{2}$ Laboratory "Horse Gene", Moscow, Russian Federation \\ *Correspondence: l.khrabrova@yandex.ru
}

\begin{abstract}
Tissue-specific protein myostatin (MSTN) is a regulator of tissue growth and differentiation. The gene determines the ratio of short and long fibers in horse muscles. Its nucleotide sequence includes several mutations (MSTN; ECA18: 66,490,208$66,495,180)$. The most interesting mutation among them from the selection point of view is g.66493737 T> C in the first intron, associated with the endurance and distance abilities of horses. Only one homozygous individual for this mutation with genotype $\mathrm{C}$ / $\mathrm{C}$ of the Vyatka breed was detected (1.11\%) during the genotyping 90 horses of 6 local breeds (Altai, Vyatka, Mezen, Pechora, Polesia, Tavda, Tuva and Yakut) using the SNP marker of the MSTN gene (g.66493737C / T). Most of the horses tested (70.14\%) had the MSTN T / T genotype. 21 horses were heterozygous for the MSTN C / T gene (28.75\%). A mutant allele was detected in representatives of seven examined breeds and was absent only in Yakut horses of the Kolyma type. The results of study the myostatin polymorphism by the g.66493737 T> C nucleotide substitution in horses of local breeds indicate that the mutant $C$ allele is found in horses of Altai, Vyatka, Pechora, Polesia, Tavda and Tuva breeds with a frequency of 0.100-0.286 and, in general, is sufficient widespread in most studied horse populations.
\end{abstract}

Keywords: genetic testing, horses, local breeds, myostatin, mutation.

\section{Introduction}

The strategy for the conservation of breed diversity includes a number of important aspects, including information on the history of creation and socio-cultural significance, direction of productivity, habitat, adaptation to natural and climatic factors and diseases, as well as genetic characteristics. An analysis of the genetic structure of domestic horse breeds at the DNA microsatellite loci conducted in the genetics laboratory of the AllRussian Research Institute of Horse Breeding showed that indigenous populations are characterized by a unique allele pool [1].

Molecular technologies today provide a reliable tool for genetic assessment of breeds, including functional (or neutral) variability within and between populations. DNA analysis helps the study of domestication, as well as the formation of productive and adaptive traits specific to each population. In 2015 the Food and Agriculture Organization of the United Nations published the lists of the most significant genetic mutations found in populations of different species of domestic animals. Two genes associated with 
performance were recommended for horse typing: myostatin (MSTN) and glycogen synthase (GYS1) [2]. Genotyping of sheep and cattle by the myostatin locus is also relevant both from the point of view of biodiversity assessment and effective selection by productive traits.

The tissue-specific protein synthesized in skeletal muscle called myostatin (MSTN) is a member of the TGF- $\beta$ super family of growth and differentiation factors which acts as a negative regulator of skeletal muscle mass deposition. It is involved in tissue differentiation starting from the embryonic stage of development. In addition to its role during skeletal muscle formation, myostatin also regulates the homeostasis of this tissue after birth. Higher levels of this protein are observed in the blood stream or muscle fibers of patients suffering from muscle loss or wasting processes, such as cachexia, muscular dystrophies and other muscle disorders [3]. The MSTN gene, composed of three exons and two introns, has been characterized in humans and several livestock species. Structural loss-of-function mutations within the coding sequence at this locus determine increased skeletal muscle mass, relevant in shoulders and thighs, and the produced phenotype is known as "double muscling" effect observed in meat breeds of cattle, sheep and fighting dogs [4-6]. The MSTN gene in horses functions to a greater extent as a factor in the differentiation of tissue growth and determines the ratio of short and long fibers in muscles. Its nucleotide sequence includes three exons localized on the 18th chromosome (MSTN; ECA18: 66,490,208-66,495,180). 19 different variants of myostatin structure were revealed at its sequencing in horses of different breeds. ). Two variants in the horse myostatin gene, including a SNP T/C in the first intron and a 227-bp SINE insertion in the promoter, are associated with muscle fiber type's proportions in the Quarter Horse $(\mathrm{QH})$ and with the prediction of race distance propensity in the Thoroughbred (TB). The $C$ allele of intron 1 was found in many cultural and native breeds of horses $[3,7,8]$.

The mutation g.66493737 $\mathrm{T}>\mathrm{C}$ in the first intron is the most interesting $[9,10]$ among them from the selection point of view. Scientists' studies have shown that Thoroughbred horses with different types of myostatin have different distance abilities due to differences in the structure and length of muscle fibers. As a rule, Thoroughbred horses with the C / C genotype exhibit sprinting abilities, while the $T$ / $T$ genotype gives an advantage to the stayers [10-12]. Horses with the $C / T$ heterozygous genotype are more versatile and are adapted to mid-range racing. A significant association has also been found between MSTN genotype and body composition, with $\mathrm{C} / \mathrm{C}$ male horses having a significantly greater body mass-to-height ratio than $\mathrm{C} / \mathrm{T}$ or $\mathrm{T} / \mathrm{T}$ horses. This is consistent with the observations that sprinters are generally more muscular and compact than individuals that are more suited to racing over longer distances [10].

At the same time, horses with the C / C and C / T genotypes are distinguished by more intensive rates of muscular development during the training process and can successfully ride at the beginning of a racing career. Based on this nucleotide substitution, a test system (Equinome Ltd, Ireland, http://www.equinome.com) was developed and put into practice. With its help it is possible to predict the remote predisposition of starting horses with an accuracy of $90 \%$.

The presence of the g.66493737 T> C mutation at the myostatin locus was detected in horses of many factory and local breeds. According to researchers, the structure of this 
locus can characterize the domestication process and phylogenetic relationships of horse breeds $[3,7,9,10,13]$.

The objective of our research was to study the distribution of g.66493737 T> C mutation of myostatin MSTN g.66493737 in horses of eight local breeds of northeast Eurasia.

\section{Material and Methods}

The hair follicles of 90 horses of eight local breeds, including the Altai $(n=7)$, Vyatka $(n=24)$, Mezen $(n=12)$, Pechora $(n=14)$, Polesia $(n=6)$, Tavda $(n=7)$, Tuva $(n=10)$ and Yakut $(n=10$, Kolyma type) served as material for research. DNA was isolated from hair follicles using the kit "ExtraGene DNA Prep 200" ("Isogen", Moscow) according standard procedure. Amplification of DNA was carried out by the method of SNP detection using proprietary primers [12]. In PCR formulation, the composition of the reaction mixture included $0.2 \mathrm{mM}$ dNTP, $0.5 \mu \mathrm{M}$ of each primer, $2.5 \mathrm{mM} \mathrm{MgCl} 2,1 \times P C R$ buffer, 1 unit Taq polymerase (PE Applied Biosystems) and 1 unit AmpliTaq Gold polymerase (PE Applied Biosystems), $50 \mathrm{ng}$ DNA. The reaction mixture was heated at $95^{\circ} \mathrm{C}$ for 5 minutes, the next 30 cycles included $40 \mathrm{C}$ denaturation at $94^{\circ} \mathrm{C}$, annealing of primers for $45 \mathrm{sec}$. at $55^{\circ} \mathrm{C}$ and elongation at $72^{\circ} \mathrm{C}$ for $45 \mathrm{sec}$. the Final elongation was carried out for 2 minutes at $72^{\circ} \mathrm{C}$.

Amplification electrophoresis was carried out in a $2 \%$ agarose gel based on a normal acetate buffer followed by staining of the fragments with a fluorescent dye as ethidium bromide. The results of electrophoresis were evaluated visually taking into account the presence of bands corresponding to different nucleotide variants in the structure of myostatin. Statistical calculations were performed using MS Excel ver. 12.

\section{Results}

Only one homozygous individual for this mutation with genotype C / C of the Vyatka breed was identified (1.11\%) during the genotyping 90 horses of 8 local breeds using the SNP marker of the MSTN gene (g.66493737C / T). Most of the horses tested (70.14\%) had the MSTN T / T genotype. Among tested horses 21 individuals were heterozygous for the MSTN C / T gene (28.75\%). A mutant allele was detected in representatives of seven examined breeds and was absent only in Yakut horses of the most northern Kolyma type (Table 1). Perhaps this feature is characteristic of the northern unique population of Yakut horses, since there is evidence of a rare occurrence of the MSTN C / T genotype in this breed [7].

Table 1. Distribution of the MSTN mutation g.66493737 T> C in the myostatin gene in horses of local breeds

\begin{tabular}{l|c|c|c|c|c|c}
\hline \multirow{2}{*}{ Breed } & \multirow{2}{*}{ N } & \multicolumn{3}{|c|}{ Genotypes (\%) } & \multicolumn{2}{c}{ Allele frequencies } \\
\cline { 3 - 7 } & & CC & CT & TT & C & T \\
\hline Altai & 7 & 0.000 & 0.571 & 0.429 & 0.286 & 0.714 \\
\hline Vyatka & 24 & 0.042 & 0.208 & 0.750 & 0.146 & 0.854 \\
\hline
\end{tabular}




\begin{tabular}{l|c|c|c|c|c|c}
\hline \multirow{2}{*}{ Breed } & \multirow{2}{*}{ N } & \multicolumn{3}{|c|}{ Genotypes (\%) } & \multicolumn{2}{c}{ Allele frequencies } \\
\cline { 3 - 7 } & & CC & CT & TT & C & T \\
\hline Polesia & 6 & 0.000 & 0.500 & 0.500 & 0.250 & 0.750 \\
\hline Tavda & 7 & 0.000 & 0.286 & 0.714 & 0.143 & 0.857 \\
\hline Tuva & 10 & 0.000 & 0.200 & 0.800 & 0.100 & 0.900 \\
\hline Yakut & 10 & 0.000 & 0.000 & 1.000 & 0.000 & 1.000 \\
\hline Mezen & 12 & 0.000 & 0.083 & 0.917 & 0.042 & 0.958 \\
\hline Pechora & 14 & 0.000 & 0.286 & 0.714 & 0.143 & 0.857 \\
\hline
\end{tabular}

The frequency of occurrence of the MSTN g.66493737 T> C nucleotide substitution in horses of 7 local breeds ranged from 0.042 (Mezen) to 0.286 (Altai), which indicates a pronounced polymorphism of the myostatin locus (Figure 1). The presence of this mutation in horses of local breeds of different countries, including Russia, gives reason to believe that it already existed in the genome of their ancient ancestors during the domestication. It should be noted that this mutation was not found in Przhevalsky's horse and various subspecies of donkeys [9].

Several mutations may already have played a role in more general adaptation to domestication. The presence of a nucleotide replacement in the first intron of myostatin g.66493737 T> C in horses of the studied native breeds indicates that it can be considered as a gene-candidate of adaptive traits. Selection of many local breeds (Altai, Tuva, Yakyt), especially in areas of herd horse breeding, is conducted on meat qualities. In such conditions preference should be given to selecting horses and especially sires with genotypes $\mathrm{C} / \mathrm{C}$ and $\mathrm{C} / \mathrm{T}$.

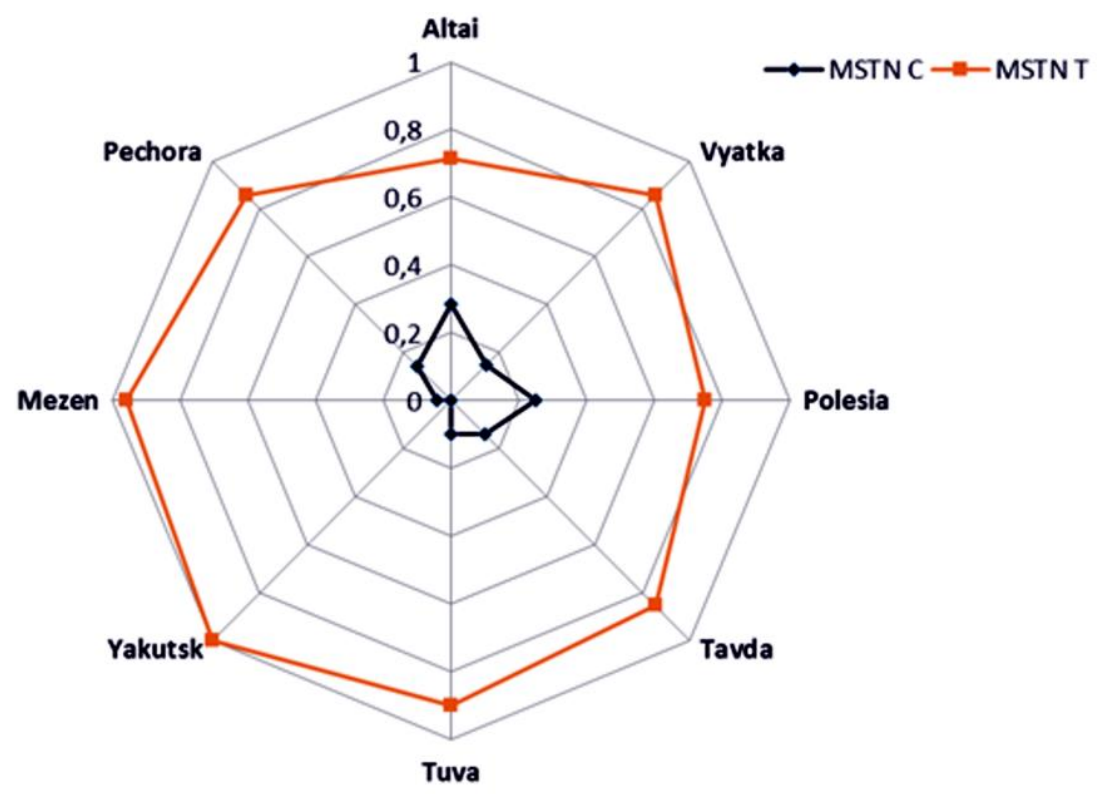

Figure 1. The frequency of occurrence of myostatin alleles (MSTN g.66493737 T> C) in horses of local breeds 
The leader having the MSTN C allele among the cultural breeds of horses is a thoroughbred horse breed which is characterized by a maximum frequency of occurrence (up to 64\%). Testing of thoroughbred riding horses by marker genes, including the myostatin locus, makes it possible to predict the racing potential of horses at 70 percent. Noteworthy is the relatively low frequency of occurrence of the mutant allele MSTN g.66493737 T> C (and even its absence) in northern forest species of horses, such as Mezen and Yakut of Kolyma types. This may be due to the minimal influence of breeds on the breeding system or the influence of the environment.

\section{Conclusions}

The results of studying the MSTN myostatin polymorphism by the g.66493737 T> C nucleotide substitution in horses of 8 local breeds indicate that the mutant $C$ allele is found in horses of Altai, Vyatka, Pechora, Polesia, Tavda and Tuva breeds with a frequency of 0.100-0.286 and, in general, quite widespread in most studied horse populations. Most of the horses tested (70.14\%) had the MSTN T / T genotype. 21 horses were heterozygous for the C / T gene (28.75\%). MSTN can be considered as a candidate gene of adaptive traits.

\section{Acknowledgments}

The research was supported by the Russian Science Foundation (Pproject No. 19-76-20058)

\section{References}

(1) Kalashnikov, V. V.; Zaitsev, L. A.; Khrabrova, A. M. The Study of Satellite DNA Polymorphism of Horses of Factory and Local Breeds (in Russian). Reports of the RAAS 2010, 6, 48-50.

(2) Scherf, B. D.; Pilling, D. The Second Report on the State of the World's Animal Genetic Resources for Food and Agriculture; Commission on Genetic Resources for Food and Agriculture, Food and Agriculture Organization of the United Nations: Rome, 2015.

(3) Petersen, J. L.; Mickelson, J. R.; Rendahl, A. K.; Valberg, S. J.; Andersson, L. S.; Axelsson, J.; Bailey, E.; Bannasch, D.; Binns, M. M.; Borges, A. S.; et al. Genome-Wide Analysis Reveals Selection for Important Traits in Domestic Horse Breeds. PLoS Genetics 2013, 9 (1), e1003211. https://doi.org/10.1371/journal.pgen.1003211.

(4) Liu, D.; Xu, Q.; Zang, L.; Liang, S.; Wu, Y.; Wei, S.; Jiang, Y. Identification and Genetic Effect of Haplotypes in the Promoter Region of Porcine Myostatin Gene: Myostatin Haplotypes and Effect in Pigs. Animal Genetics 2011, 42 (1), 6-14. https://doi.org/10.1111/j.1365-2052.2010.02081.x.

(5) Mosher, D. S.; Quignon, P.; Bustamante, C. D.; Sutter, N. B.; Mellersh, C. S.; Parker, H. G.; Ostrander, E. A. A Mutation in the Myostatin Gene Increases Muscle Mass and Enhances Racing Performance in Heterozygote Dogs. PLoS Genetics 2007, 3 (5), e79. https://doi.org/10.1371/journal.pgen.0030079. 
(6) Sarti, F. M.; Lasagna, E.; Ceccobelli, S.; Di Lorenzo, P.; Filippini, F.; Sbarra, F.; Giontella, A.; Pieramati, C.; Panella, F. Influence of Single Nucleotide Polymorphisms in the Myostatin and Myogenic Factor 5 Muscle Growth-Related Genes on the Performance Traits of Marchigiana Beef Cattle1. Journal of Animal Science 2014, 92 (9), 3804-3810. https://doi.org/10.2527/jas.2014-7669.

(7) Voronkova, V. N.; Stolpovsky, Y. Assessment of the Genetic Diversity of Native Breeds of the Sayan-Altai Region Using Nuclear and Mitochondrial DNA Markers (in Russian). In Indigenous horse breeding of Russia: history, modernity, prospects: collection of scientific papers; FICKIA RAN: Arkhangelsk, 2018; pp 60-69.

(8) Gabor, M.; Miluchova, M.; Trakovicka, A. Development of ACRS-PCR Method for Detection of Single Nucleotide Polymorphism g.66493737C/T of the Equine Myostatin Gene (MSTN. Scientific Papers: Animal Science and Biotechnologies 2014, 47 (2), 52-55.

(9) Dierks, C.; Momke, S.; Philipp, U. The Myostatin Sequence Variant g.66493737T>C Detects Evolution and Domestication in Horses. In Book of Abstracts of the 63rd Annual Meeting of the European Federation of Animal Science; Wageningen Academic Publishers: Bratislava, Slovakia, 2012; Vol. 18, p 324.

(10) Hill, E. W.; Gu, J.; McGivney, B. A.; MacHugh, D. E. Targets of Selection in the Thoroughbred Genome Contain Exercise-Relevant Gene SNPs Associated with Elite Racecourse Performance: SNP Association with Elite Racing Performance. Animal Genetics 2010, 41, 56-63. https://doi.org/10.1111/j.1365-2052.2010.02104.x.

(11) Binns, M. M.; Boehler, D. A.; Lambert, D. H. Identification of the Myostatin Locus (MSTN) as Having a Major Effect on Optimum Racing Distance in the Thoroughbred Horse in the USA: Identification of MSTN. Animal Genetics 2010, 41, 154-158. https://doi.org/10.1111/j.1365-2052.2010.02126.x.

(12) Aidarov, V. A.; Vikulova, L. L.; Sorokin, S. I. The Study of Polymorphic Variants of the Myostatin Gene Associated with the Racing Distance Abilities of Horses of Thoroughbred Riding Breed (in Russian). Konevodstvo $i$ Konny Sport (Horse Breeding and Equestrian Sports) 2017, 4, 14-15.

(13) Kalinkina, G. V.; Sorokin, S. I.; Yu.A. Orlova, V. V. K.; Makhmutova, O. N. The Study of MSTN Myostatin Polymorphism in Oryol Trotters with Different Distance Abilities (in Russian). Konevodstvo i Konny Sport (Horse Breeding and Equestrian Sports) 2017, 1, 13-15.

\section{Information about Authors}

Lyudmila Aleksandrovna KHRABROVA: D.Sc. in Agriculture, Professor, Chief Researcher of the All-Russian Research Institute of Horse Breeding; 35 apt. 29 (All-Russian Research Institute of Horse Breeding), Divovo (Settlement), Rybnovsky District, Ryazan Region, 391105, Russia; e-mail: I.khrabrova@yandex.ru; ORCID ID: https://orcid.org/0000-0003-2590-8472. 
Sergey Ivanovich SOROKIN: Ph.D. in Agriculture, Head of the Laboratory "Horse Gene"; 6/1-128 Sumsky Str., Moscow, 117208, Russia; e-mail: sorokinsergey77@gmail.com; ORCID ID: https://orcid.org/0000-0002-0012-413X.

Nina Vasilievna BLOKHINA: Ph.D. in Agriculture, Researcher, Genetics Laboratory, All-Russian Research Institute of Horse Breeding; 26 (All-Russian Research Institute of Horse Breeding), Divovo (Settlement), Rybnovsky District, Ryazan Region, 391105, Russia; e-mail: nbloh16@yandex.ru; ORCID ID: https://orcid.org/0000-0001-7406-6385.

Tatyana Valerievna KALASHNIKOVA: Senior Researcher, Genetics Laboratory, All-Russian Research Institute of Horse Breeding; 7 (All-Russian Research Institute of Horse Breeding), Divovo (Settlement), Rybnovsky District, Ryazan Region, 391105, Russia; e-mail: taina.cessi@gmail.com; ORCID ID: https://orcid.org/0000-0002-7957-1679. 